\title{
PENDEKATAN-PENDEKATAN DALAM BELAJAR BAHASA
}

\author{
Oleh: Dr. Umi Hijriyah, M. Pd.
}

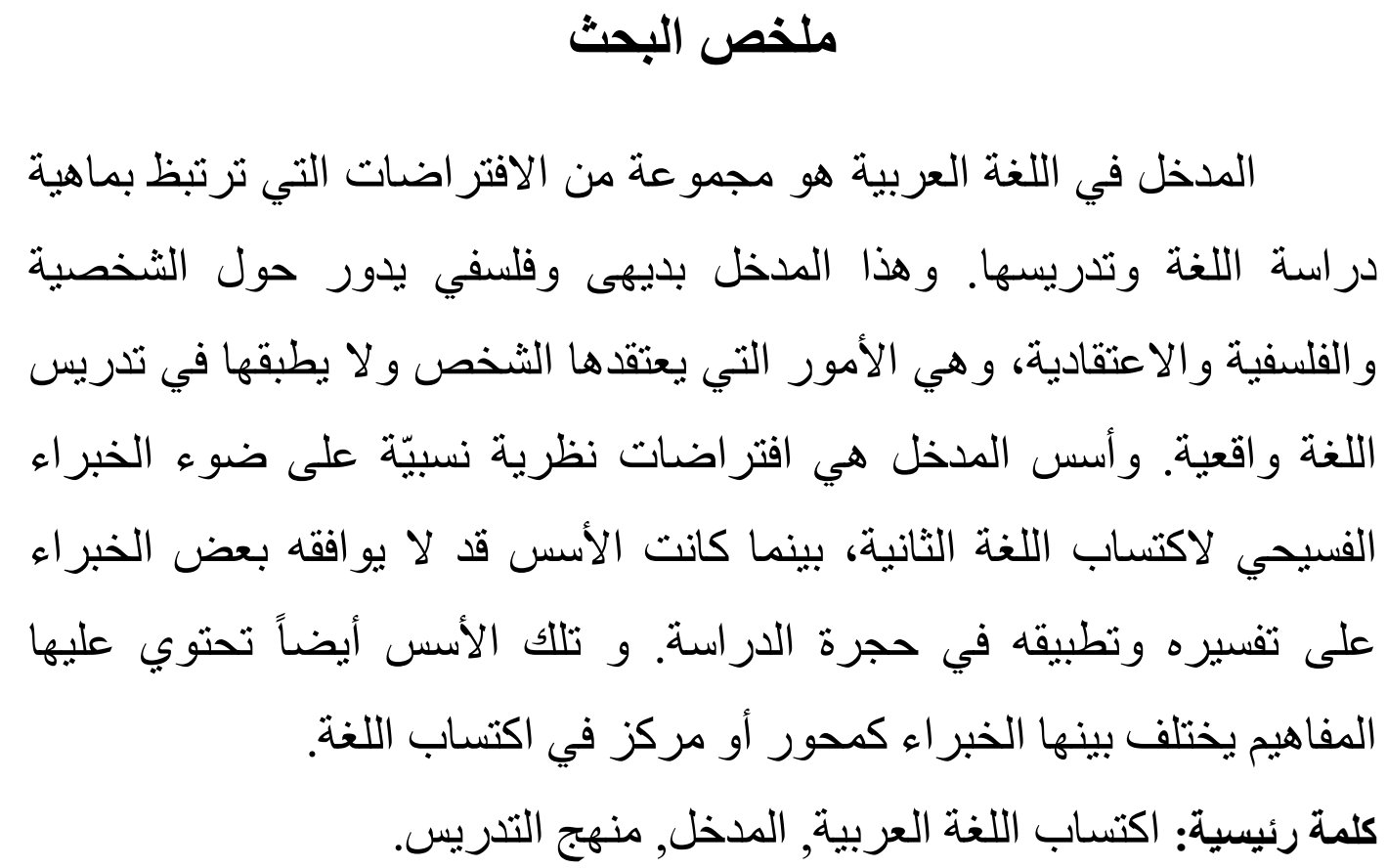

\section{A. Pendahuluan}

Pendekatan atau approach yang dalam bahasa Arab disebut madkhaladalah "seperangkat asumsiberkenaan dengan hakikat belajar dan mengajar bahasa. Pendekatan bersifat axiomatic atau filosofis yang berorientasi pada pendirian, filsafat, dan keyakinan yaitu sesuatu yang diyakini tetapi tidak mesti dapat dibuktikan"1. Suatu pendekatan dalampembelajaran bahasa bukan hanya serangkaian prinsip-prinsip mati "yang kaku”. Sesungguhnya ini merupakan perpaduan energi dalam seorang guru yang dinamis (atau seharusnya berubah, jika itu adalah guru yang tumbuh berkembang) dengan berlanjutnya pengalaman dalam pembelajaran dan pengajaran. Terlalu jauh ketika kita tidak mengetahui proses ini secara kolektif, dan terlalu banyak temuan penelitian tentang hal tersebut untuk mengasumsikan bahwa seorang guru bisa dengan

${ }^{1}$ Abdul Wahab Rosyidi dan Mamlu'atul Ni'mah, Memahami Konsep Dasar Pembelajaran Bahasa Arab, UIN Maliki Press, tahun 2012, hal.33. 
percaya diri mengatakan bahwa ia mengetahui segala sesuatu yang perlu diketahui tentang bahasa dan pembelajaran bahasa.

Tentu saja pendekatan seorang guru bisa berbeda dengan beragam persoalan dari rekannya, atau bahkan dengan "para ahli” di bidangnya, yang saling berbeda satu sama lain. Ada dua alasan beragam atas beragam tingkat pendekatan itu: (1) sebuah pendekatan secara definitif bersifat dinamis dan oleh karena itu tunduk terhadap beberapa "prinsip" sebagai akibat pengalaman dan pengamatan seseorang; dan (2) penelitian dalam pemerolehan bahasa kedua dan pedagogi hampir selalu menghasilkan temuan-temuan yang tunduk terhadap interpretasi ketimbang memberikan bukti yang bersifat menyimpulkan.

Interaksi antara pendekatan seseorang dengan praktik di dalam ruang kelas adalah kunci pengajaran yang dinamis. Para guru terbaik bisa menghitung resiko di dalam ruang kelas: ketika dirasakan ada kebutuhan siswa yang baru, maka dicoba teknik-teknik pedagogik inovatif, dan tindak lanjut penilain menghasilkan penilain yang teramati atas efektifitasnya. Inspirasi awal inovasi-inovasi semacam itu datang dari tingkat pendekatan, namun umpan balik yang dikumpulkan para guru berasal dari penerapan nyata kemudian membentuk ulang dan memodifikasi keseluruhan pemahaman mereka tentang apa itu pembelajaran dan pengajaran yang kemudian bisa memunculkan wawasan-wawasan baru dan kemungkinankemungkinan yang lebih inovatif, dan siklus tersebut berlanjut.

\section{B. Macam-macam Pendekatan Pembelajaran Bahasa Arab}

Dalam pengajaran bahasa Arab dikenal lima macam pendekatan ${ }^{2}$, yaitu:

\section{Pendekatan Kemanusiaan (Humanistic Approach)}

Pendekatan kemanusiaan yang dalam bahasa Arab disebut dengan al madkhal al insani. Pendekatan ini sangat memfokuskan pada peserta didik. Peserta didik dipandang sebagai manusia yang harus diperlakukan secara manusiawi, bukan alat atau benda mati yang menerima rangsangan-rangsangan dan meresponnya. Perskpektif ini menurut sebagian ahli pengajaran bahasa asing merupakan

${ }^{2}$ Radliyah Zainudin, dkk.,Metodologi dan Strategi Alternatif Pembelajaran Bahasa Arab, Yogyakarta: Pustaka Rihlah Group, 2005, hal. 33-36. 
orientasi baru yang biasanya menganggap peserta didik sebagai obyek yang dapat dibentuk semaunya, tanpa melihat minat, dan bakat mereka. Dengan pola pandang ini setidaknya dapat mempercepat interelasi antara pengajar dan siswa dalam hubungannya dengan proses tranfering knowledge, karena kebutuhan psikologis siswa dapat terpenuhi, serta minat dan motivasinya dapat dikembangkan.

\section{Pendekatan Berbasis Media (Media Based Approach)}

Pendekatan berbasis media yang dalam bahasa Arab disebut al-madkhol altiqoni, adalah pendekatan yang mengandalkan kepada teknik penggunaan media pengajaran. Sebagaimana diketahui bahwa sarana atau alat peraga (alat bantu) besar peranannya dalam menyampaiakan keahlian dan mengubahnya dari keahlian abstrak kepada keahlian yang kongkrit. Pendekatan ini bertujuan untuk melengkapi konteks yang menjelaskan makna kata-kata, struktur dan istilah-istilah kebudayaan baru melalui gambar, peta, foto, contoh model hidup, kartu dan segala sesuatu yang membantu menjelaskan makna kata asing kepada siswa. Pada zaman cangggih alat bantu menjadi lebih bervariatif dan lebih modern lagi. Seperti: kaset, radio, slide, dan computer. Pendekatan ini sering menghadapi kendala khususnya berkaitan dengan biaya pengadaan alat peraga serta tidak lengkapnya materi pengajaran yang berkualitas.

\section{Pendekatan Aural-Oral (Aural-Oral Approach)}

Pendekatan Aural-Oral yang dalam bahasa Arab disebut al madkhol alsama'i al syafahi.Pendekatan ini memiliki asumsi bahwa bahasa adalah yang didengar dan apan yang diucapkan, sedangkan tulisan hanyalah representasi dari ujaran.Berangkat dari asumsi ini, maka bahasa yang pertama adalah ujaran.Untuk itu pengajaran bahasa harus dimulai dengan memperdengarkan bunyi-bunyi bahasa dalam bentuk kata atau kalimat secara klasikal kemudian meminya siswa menirukannya. Untuk kemudian dihafalkan, sebelum pembelajaran membaca dan menulis diajarkan. Berkembangnya komunikasi yang mendekatkan jarak antara individu yang lain serta kebutuhan kepada bahasa untuk dipergunakannya dalam komunikasi lisan merupakan motivasi lahirnya pendekatan ini. Asumsi ini diperkuat dengan adanya faktor kebiasaan.Karena suatu prilaku akan menjadi 
kebiasaan apabila diulang berkali-kali. Begitupula dengan pengajaran bahasa harus dilakukan dengan teknik pengulangan atau repetisi.

\section{Pendekatan Analisis dan Non Analisis (Analytical and Non Analytical Approach)}

Pendekatan Analisis dan Non Analisis yang dalam bahasa Arab disebut almadkhol al-tahlili wag hair al-tahlili, adalah pendekatan yang digagas oleh Stern dalam Kongres tahun 70-an, dan konsep pendekatan ini lebih dipertajam pada kongres terakhir yang diselenggarakan pada bulan Nopember 1980. Pendekatan ini sering disebut dengan pendekatan formal, karena ia memantulkan orientasi lairan sastra tentang analisa bentuk-bentuk percakapan, pidato, dan teorikominikasi lisan.

Perbedaan antara analisis dan non analisis dalam perspektif ini adalah sebagai berikut: (1) pendekatan analisis adalah pendekatan yang menjadikan sosiolinguistik sebagai dasar pertimbangan analisis. Diskursus ini memfokuskan diri pada pembahasan semantic, aktifitas bicara, analisis sistem dan pengertianpengertian fikiran serta menuntut penganalisaan kebutuhan sosio-linguistik, program bahasa baru dan program professional yang didasarkan pada silabus.Sedangkan (2) pendekatan non analisis adalah pendekatan yang menjadikan pembahasan psyco-linguistik dan ilmu pendidikan sebagai asas pertimbangan analisis yang bersifat global.Integral dan alami.Pendekatan ini menuntut pengajaran bahasa pada situasi-situasi kehidupan yang alami dan difokuskan kepada topik-topik pembicaraan yang berkaitan dengan psykologis siswa.

\section{Pendekatan Komunikatif (Coomunicative Approach)}

Pendekatan Komunikatif yang dalam bahasa Arab disebut al-madkhol alittishaali, adalah pendekatan yang memfokuskan kepada kemampuan komunikasi aktif dan praktis. Menurut para pemerhati bahasa, pendekatan initelah melakukan terobosan baru yang strategis dibidang pembelajaran bahasa kedua, dan dianggap sebagai pendekatan yang integral dan memiliki ciri-ciri yang pasti. Hal ini Karena 
pendekatan tersebut merupakan perpaduan strategi-strategi yang bertumpu pada satu tujuan tertentu yang pasti. Yaitu melatih siswa menggunakan bahasa secara langsung (spontanitas) dan kreatif. disamping penguasaan tata bahasa.Prinsipprinsip pendekatan ini mendorong siswa untuk berani menggunakan bahasa Arab.Sedangkan fokusnya adalah menyampaikan makna atau maksud yang tepat sesuai dengan tuntutan dan fungsi komunikasi pada waktu itu. Sedangkan tata bahasa dalam perspektif pendekatan ini hanyalah sekedar pengetahuan akan makna kalimat dan jabatan kata-katanya, sehingga peserta didik diharapkan dapat mengungkapkan pikiran, peasaan, kemauan dan keyakinan berlandaskan pada kaidah.

\section{Pendekatan Pembelajaran Aktual}

Dari perubahan proses pembelajaran yang berpusat pada guru menuju pembelajaran yang berpusat pada siswa melahirkan berbagai pendekatan pembelajaran yang bertujuan untuk membelajarkan siswa.Diantaranya adalah; pendekatan konstruktivisme, Pendekatan kontekstual, Quantum Pembelajaran dan pengajaran, pembelajaran kooperatif, dan PAKEM atau PAIKEM. ${ }^{3}$

Saya ingin mengungkapkan bahwa pendekatan-pendekatan yang sekarang bertahan pada pengajaran bahasa adalah pendekatan yang "dibuat prinsip", dimana mungkin sejumlah prinsip-prinisp berdasar penelitian umum yang terbatas tempat pijakan praktik di ruang kelas. Sebelas prinsip yang saya daftar dan definisikan di bagian ini adalah sejumlah hal yang bertahan yang saya nyatakan merupakan asumsi-asumsi teoritis yang secara relatif diterima secara luas tentang pemerolehan bahasa kedua kadang ada ketidaksetujuan dalam interpretasinya dan terapannya dalam ruang kelas, namun prinsip-prinsip tersebut mengandung tubuh gagasan yang sedikit diperselisihkan sebagai pusat sebagian besar kontek pemerolehan bahasa. Prinsip-prinsip tersebut dirangkum secara ringkas disini.

\footnotetext{
${ }^{3}$ Aziz Fakhrurrozy, Taeaching English as a Foreign Languange For Teaches in Indonesia, English Departement-Faculty Of Letters The State University Of Malang.2010, hal. 44-51.
} 


\section{a. Otomatis}

Pembelajaran bahasa kedua yang efisien meliputi pergerakan kontrol yang tepat waktu atas bentuk-bentuk bahasa ke dalam pemrosesan otomatis sejumlah bentuk-bentuk bahsa yang relatif tak terbatas.Terlalu menganalisa bahasa, terlalu banyak berfikir tentang bentuk-bentuknya, dan terlalu terikat dengan aturan-aturan bahasa secara sengaja cenderung merintangi jalan untuk menuju menjadi otomatis.

\section{b.Pembelajaran yang bermakna}

Pembelajaran yang bermakna akan mengarahkan kepada penyimpanan (ingatan) jangka panjang yang lebih baik ketimbang pembelajaran secara hafalan. Salah satu dari banyak contoh pembelajaran yang bermakna ditemui dalam pendekatan-pendekatan berpusat-pada-muatan terhadap pengajaran bahasa.

\section{c. Antisipasi dengan penghargaan}

Manusia secara universal terdorong untuk bertindak, atau "berperangai" dengan antisipasi atas beberapa jenis penghargaan - yang nampak ataupun tak nampak, jangka pendek maupun jangka panjang, yang akan terjadi sebagai akibat perilaku. Meskipun keberhasilan jangka panjang dalam pembelajaran bahasa membutuhkan motif yang bersifat lebih intrinsik, kekuatan penghargaan yang bersifat segera dalam kelas bahasa tak bisa dibantah. Salah satu tugas guru adalah menciptakan kesempatan-kesempatan bagi saat-saat dengan penghargaan yang bisa membuat kelas tetap menarik atau menggairahkan.

\section{d.Motivasi intrinsik (dari dalam diri)}

Kadang, perilaku yang terdorong oleh penghargaan bersifat bergantung pada motivasi luar (ekstrinsik) [yang diberikan secara eksternal oleh orang lain]. Namun kategori penghargaan yang lebih kuat adalah yang secara intrinsik berasal dari dalam pembelajar sendiri.Ketika perilaku yang berasal dari kebutuhan, keinginan, atau gairah dari dalam diri orang sendiri, perilaku itu sendiri memiliki potensi penghargaan oleh diri sendiri. Dalam kontek seperti itu, secara penghargaan yang diberikan dari luar (eksternal) tidaklah perlu; para pembelajar 
akan memelihara perilaku tersebut diluar kehadiran guru, orang tua, dan tutor lainnya.

\section{e. Investasi strategis}

Penguasaan bahasa kedua yang berhasil pada isis yang lebih luas merupakan hasil "investasi" pribadi pembelajar sendiri atas waktu, usaha, dan perhatian terhadap bahasa kedua dalam bentuk tenaga baterei individu atas strategi pemahaman dan menghasilkan bahasa.

\section{f. Ego bahasa}

Ketika manusia menggunakan sebuah bahasa kedua, mereka mengembangkan mode baru dalam berpikir, merasakan, dan bertindak - yang merupakan identitas kedua."Ego bahasa" baru yang terjalin dalam bahasa kedua bisa dengan mudah tercipta dalam perasaan rentan, bertahan diri, dan munculnya penghalang dalam diri seorang pembelajar.

\section{g. Kepercayaan diri}

Keberhasilan akhir yang dicapai pembelajar dalam suatu tugas adalah sebagian faktor kepercayaan mereka dimana mereka sesunggunhnya mampu dalam menyelesaikan tugas.Harga diri terletak pada akar dari prestasi akhir.

\section{h.Pengambil resiko}

Pembelajar bahasa yang berhasil, dalam menilai diri mereka sendiri secara realitis sebagai makhluk yang rentan meskipun bisa menyelesaikan tugas, harus rela menjadi "penjudi” dalam permainan bahasa, untuk berusaha menghasilkan dan menginterpretasikan bahasa yang sedikit di luar kepastian absolut mereka.

\section{i. Hubungan Bahasa-Budaya}

Kapanpun anda mengajar bahasa, Anda juga mengajar suatu sistem adat kebudayaan, dan nilai-nilai, dan cara berfikir, cara merasakan dan cara bertindak yang komplek. 


\section{j. Efek Bahasa Ibu}

Bahasa asli (bahasa ibu) pembelajar akan merupakan sistem yang sangat bermakna tempat para pembelajar akan bersandar untuk memprediksi sistem bahasa-target (bahasa kedua yang dipelajari). Meskipun bahwa sistem asli (bahasa asli/bahasa ibu) akan memberikan efek baik itu memudahkan maupun mengganggu (transfer positif dan transfer negatif) dalam menghasilkan dan memahami bahasa yang baru, efek yang mengganggu nampaknya adalah yang paling menonjol.

\section{k. Antar bahasa}

Para pembelajar bahasa kedua cenderung melalui proses perkembangan sistematis atau quasi-sistematis ketika mereka mengalami peningkatan ke kompetensi yang penuh dalam bahasa target (bahasa kedua yang dipelajari). Perkembangan antar bahasa yang berhasil merupakan sebagian faktor dari pendayagunaan umpanbalik dari orang lain. Para guru dalam kelas bahasa bisa menyediakan umpan balik semacam itu, namun yang lebih penting bisa membantu para pembelajar untuk menghasilkan umpan balik mereka sendiri diluar ruangan kelas.

\section{l. Kompetensi Komunikatif}

Jika kompetensi komunikatif merupakan tujuan kelas bahasa, insturki perlu diarahkan ke semua komponennya: yakni komponen organisasional, pragmatik, strategis, dan psikomotorik. Tujuan-tujuan komunikatif bisa dicabai terbaik dengan memberikan perhatian terhadap penggunaan bahasa dan bukan sekadar keguanaan, kelancaran berbahasa dan bukan sekedar ketepatan, terhadap bahasa dan konteks yang otentik (asli), dan terhadap kebutuhan nyata para siswa untuk menerapkan pembelajaran didalam kelas ke konteks dunia nyata.

\section{m. Diagnosa, Perlakuan dan Penilaian}

Pendekatan yang dibuat menjadi prinsip dalam pengajaran bahasa mendorong guru bahasa untuk terikat dalam proses diagnosa, perlakuan dan penilaian yang dibuat secara hati-hati. Hal ini memungkinkan kita untuk 
menjelaskan kebutuhan-kebutuhan komunikatif dan situasional yang diantisipasi diantara para pembelajar yang dituju, dan untuk mendiagnosa perlakuan kurikulum yang layak bagi para pembelajar tertentu dalam konteksnya yang berbeda dan untuk tujuan-tujuan tertentu mereka.Ini kemudian membantu kita untuk merancang sasaran-sasaran pedagogik yang efektif yang mempertimbangkan semua variabel kontekstual dalam kelas.Suara merupakan pendekatan komprehensif yang mendasari penciptaan serangkaian pengalaman belajar yang layak, dengan konteks dan tujuan tertentu, untuk mewujudkan sasaran-sasaran yang ditetapkan. Ini memungkinkan para guru untuk menilai apa yang berjalan dengan benar dan salah dalam pelajaran, untuk secara sistematik mengevaluasi penyelesaian sasaran-sasaran kurikulum. Dan ini juga membantu mereka dalam merevisi aktifitas, pelajaran, material dan kurikulum.

\section{DIAGNOSA}

Fase pertama tahap diagnostik pedagogi bahasa mulai dengan rencana kurikulum dan berlanjut dengan proses monitoring yang berjalan di ruang kelas. Kurikulum bahasa membutuhkan studi awal yang oleh Richards (1990) disebut kebutuhan "situasional", atau konteks pengajaran. Kebutuhan situasional meliputi pertimbangan kelembagaan negara, latar belakang sosial ekonomi dan pendidikan siswa, tujuan tertentu yang dimiliki siswa dalam pembelajaran bahasa, dan batasan kelembagaan yang diharuskan dalam sebuah kurikulum. Beberapa dari sebelas prinsip yang disebutkan tadi terlibat dalam mengisolasikan kebutuhan situasional:

a) Apakah ketrampilan berbahasa dirasakan oleh para siswa sebagai hal yang termotivasi dari dalam diri sendiri?

b) Seberapa jauh bahasa yang dipertanyakan melibatkan para siswa dalam bergulat dengan "identitas baru" dan oleh karenanya menyiratkan persoalan ego bahasa?

c) Apa hubungan antara bahasa target dan budaya asli si siswa? 
Induk dari prinsip-prinsip pendidikan, sosiologis, dan adminsitratif berperan dalam menentukan kebutuhan situasional; ada namun seidkit.

Fase kedua perkembangan kurikulum ditandai dengan rincian kebutuhan linguistik - kadang disebut juga dengan kebutuhan "komunikatif” bentuk-bentuk dan fungsi-fungsi bahasa tertentu yang harus diprogramkan dalam garis pokok pembelajaran. Di sini sekali lagi prinsip-prinsip tertentu dalam pembelajaran dan pengajaran menginformasikan pilihan-pilihan kita:

a) Seberapa jauh kontras bahasa ibu dan bahasa target (bahasa kedua yang dipelajari) penting untuk diperitmbangkan?

b) Bagaimana seharusnya rancangan sistematika antarbahasa dan ragam efek kurikulum?

c) Apa yang dikatakan oleh analisa kontrastif, antarbahasa dan kompetensi komunikatif kepada kita tentang ururt-urutan bentuk dan fungsi linguistik dalam sebuah kurikulum?

d) Bagaimana kurikulum bisa mewujudkan prinsip keotentikan (keaslian)?

Yang tak kalah pentingnya dalam tahap perencanaan mata pelajaran bahasa adalah adalah penilaian diagnosis khusus untuk setiap siswa ketika memasuki program. Setelah pelajaran direncanakan secara baik, dengan pilihanpilihan pedagogis yang terjalin rumit didalamnya, bagaimana guru bisa menjadi ilmuwan dan seniman diagnosa yang secara hati-hati memunculkan produksi dan pemahaman bahasa pada setiap siswa? Bagaimana pemunculan itu diukur dan dinilai sebegitu rupa sehingga pelajaran bahasa bisa sedikit banyak dimodifikasi untuk memenuhi kebutuhan siswa tertentu yang terjadi di suatu kelas pada saat itu?

Tak ada satupun dari pertanyaan kompleks ini yang bisa dijawab dengan metode-metode yang sekarang membumi dalam profesi pengajaran bahasa fase diagnosa yang sangat penting dalam pelajaran bahasa menghindari pertimbangan apapaun atas metode yang sebelumnya telah dipaketkan untuk diberikan ke seluruh pembelajar. Salah satu bidang penting pertanyaan dalam profesi sekarang 
ini adalah tahapan diagnosa, yang secara lebih cukup menunjukkan kebutuhan linguistik pembelajar ketika mereka memasuki program studi.

\section{PERLAKUAN}

Orang mungkin tergoda berpikir tentang "perlakuan" sebagai tahapan yang layak untuk penerapan metode-metode.Orang masih bisa menjumpai orang berargumen misalnya, bahwa jika fase diagnosa menemukan pembelajar yang membutuhkan banyak aktifitas fisik, sedikit penjelasan metalinguistik, dan guru yang sangat memberi arahan, maka pastilah Respon Fisik Total (atau TPR ${ }^{4}$ ) merupakan perlakuan yang harus ditawarkan. Permasalahan dengan kesimpulan ini adalah bahwa hal ini terlalu digeneralisasikan dan terlalu membatasi. Beberapa pembelajar sesungguhnya bisa mengambil manfaat dari teknik-teknik TPR yang dosisnya jarang, namun tentu saja kompleknya proses pemerolehan bahasa kedua menginginkan beberapa perlakuan dan pendekatan terhadap pelajaran bahasa. Prinsip-prinsip yang secara kolektif mendasari metode tersebut seperti kita tahu memberikan sedikit hubungan valid suatu pendekatan kepada diagnosa dan perlakuan, namun satu metode tunggal jauh lebih sempit membatasi kemungkinan-kemungkinan untuk mencukupi keseluruhan kurikulum.

Banyak pokok persoalan yang disoroti di bagian ini yang akan muncul kembali disepanjang kumpulan paper ini. Di banyak paper, para penulis menggambarkan pendekatan-pendekatan terhadap pengajaran yang diinformasikan oleh teori dan praktik pendidikan dan memberi contoh di banyak permasalahan yang disentuh oleh Brown dalam papernya, seperti halnya juga pemikiran-pemikiran pengajaran lain yang dideskripsikan oleh Richards. Disaat yang bersamaan, banyak paper menggambarkan pemecahan-pemecahan masalah yang unik dan bersifat pribadi terhadap permasalahan dan pokok persoalan yang sering ditemui oleh guru secara individual atau oleh sekelompok guru dalam pengajaran mereka, dengan menunjukkan bahwa bagi banyak guru, proses mengajar sehari-hari adalah sejenis penelitian dan percobaan yang berjalan.

\footnotetext{
${ }^{4}$ Dari istilah aslinya Total Physical response disingkat TPR)
} 
Banyak guru menemukan gagasan metode yang menarik di seratus tahun terakhir, karena nampaknya mereka menawarkan sistem-sistem yang terbukti bodoh untuk instruksi di ruang kelas dan disini kadang dipegang secara antusias sebagai obat mujaran untuk "permasalahan pengajaran bahasa". Tahun 1970-an dan 1980-an mungkin merupakan tahun-tahun antusiasme terbesar terhadap metode-metode tersebut. Di dalam apa yang disebut dengan "era pasca metode", perhatian bergeser ke pengajaran dan proses pembelajaran serta sumbangan-sumbangan guru individual terhadap pedagogi pengajaran bahasa.

Brown membahas sejumlah alasan menurunnya sindrom metode dalam pembahasan kontemporer pengajaran bahasa. Seperti komentar dirinya dan juga orang lain, gagasan tentang "metode perancang: untuk banyak tujuan yang akan bekerja di manapun dan untuk siapapun memunculkan sejumlah permasalahan:

a) Metode-metode bercirikan pembebanan dari-atas-ke-bawah dari pandangan para ahli pengajaran. Peran guru secara individual diminimalkan. Peran guru secara individual adalah untuk menerapkan dan menyesuaikan gaya pengajarannya untuk cocok dengan metode. Metode-metode disini bersifat seperti resep.

b) Metode-metode gagal untuk mencermati konteks pengajaran dan pembelajaran yang lebih luas serta berfokus hanya kepada sebagian kecil dari serangkaian elemen-elemen yang lebih komplek. Brown menggambarkan hal yang disebut sebagai pendekatan "pengembangan kurikulum" kepada pengajaran, yang dimulai dengan diagnosa (seperti analisa kebutuhan, silabus, dan pengembangan material), kemudian bergerak ke perlakuan (seperti instruksi dan pedagogi), dan melibatkan permasalahan-permasalahan penilaian (seperti ujian dan evaluasi).

Bagi Brown, istilah metode bisa digantikan secara terbaik dengan istilah pedagogi. Metode menyiratkan serangkaian prosedur statis (mati), sementara pedagogi mengungkapkan dinamika yang saling mempengaruhi antara para guru, pembelajar, dan material instruksi selama proses pengajaran dan pembelajaran. Brown mencirikan dasar pedagogi pengajaran bahasa dalam ihwal prinsip-prinsip 
yang mencerminkan penelitian dan teori tentang pemerolehan bahasa kedua yang kini sedang berjalan.

Richards berupaya menunjukkan betapa tiga pemikiran yang berbeda atas pengajaran di sejarah pengajaran bahasa yang terjadi kini telah mengarahkan ke pemahaman yang berbeda atas keterampilan esensial para guru dan terhadap pendekatan-pendekatan yang berbeda terhadap pelatihan guru dan pengembangan guru. Pemikiran penelitian-ilmiah atas pengajaran berupaya mengembangkan metode-metode pengajaran dari terapan-terapan hasil penelitian, dan melihat peningkatan pengajaran sebagai hal yang berkaitan dengan penelitian kedalam pembelajaran, motivasi, ingatan, dan faktor-faktor terkait.Pengajaran yang baik adalah suatu pertanyaan atas penerapan temuan-temuan dalam penelitian. Pengajaran Bahasa Berdasarkan tugas dan usaha-usaha untuk menerapkan penelitian otak kepada pengajaran adalah contoh terkini atas pendekatan ini.Pemikiran-pemikiran tentang filsafat-teori pengajaran berasal dari pemahaman "akal sehat" rasional pengajaran atau dari sistem nilai atau ideologi, ketimbang berasal dari penelitian. Pengajaran Bahasa Komunikatif adalah contoh bagus pendekatan ini, karena pendekatan ini didasarkan pada suatu ideologi ketimbang agenda suatu penelitian, seperti juga halnya gerakan-gerakan seperti Teori Kritis dan Pedagogi Kritis. Para pendukung gerakan ini melihat misi mereka sebagi meyakinkan para guru tentang benarnya teori tersebut, untuk mengkajai pengajaran mereka untuk melihat seberapa jauh teori tersebut sesuai dengan nilainilai mereka, dan berupaya menggabungkan prinsip-prinsip atau nilai-nilai yang relevan ke dalam pengajaran mereka. Pemikiran seni-kerajinan dalam pengajaran, sebagai perbandingan, melihat pengajaran yang baik sebagai seuatu yang unik dan bersifat prinadi pada tiap guru. Teori mengajar dipandang sebagai sebagai sesuatu yang dibangun oleh para guru secara individual. Dari sudut pandang ini, pengajaran dipandang sebagai hal yang didorong oleh usaha para guru untuk menyatukan teori dan praktik.Program-program pendidikan-guru memberi dasar teori akademik dan penelitian bagi para guru, yang mereka uji terhadap kenyataan praktik pengajaran. Dengan begitu mereka menciptakan pemahaman pengajaran 
mereka sendiri, yang diperluas dan direvisi ketika mereka mengelola masalahmasalah baru dan memperdalam dasar pengetahuan dan pengalaman mereka dalam pengajaran

"Perlakuan-perlakuan" bahasa kedua bisa dianggap sebagai garis besar pokok perencanaan pengajaran atau lebih baik lagi, serangkaian pengalaman pembelajaran, yang dirancang untuk menargetkan kebutuhan pembelajar yang diungkap melalui penilaian diagnostik.Untuk perlakuan semacam itu, profesi menawarkan sejumlah pilihan yang luar biasa banyak. Sebagai sebuah awalan, pertimbangkan 38 tehnik pengajaran bahasa yang dikategorikan oleh Crookes dan Cahudron $^{5}$ yang mulai dari tehnik terkontrol (latihan, dialog, membaca dengan keras, mengutarakan pertanyaan/jawaban, dan lain-lain) ke teknik semi terkontrol (pertanyaan/jawaban rujuan, narasi dengan isyarat, aktifitas kesenjangan informasi, dan lain-lain) hingga tehnik bebas (bermain peran, pemecahan masalah, wawancara, diskusi, dan lain-lain). Pertimbangkan pula banyaknya aktifitasaktifitas seperti pasangan-kerja, seluruh-kelas, kelompok-kerja yang bisa kita pilih. Kemudian lihatlah gunungan buku naskah dan material lain yang disajikan pada konferensi pengajaran bahasa utama !ini merupakan tugas guru untuk memilih secara hati-hati dan sadar diantara banyaknya pilihan untuk merumuskan runtutan teknik pedagogik di kelas. Dan di sinilah pilihan-pilihan seorang guru harus dijadikan "prinsip".

Satu cara untuk melihat pilihan-pilihan yang dijadikan prinsip bagi perlakuan adalah seberapa jauh suatu teknik meningkatkan tujuan yang diinginkan. Contohnya, andaikan seorang guru ingin memberikan teknik-teknik yang berupaya menciptakan motivasi intrinsik dalam diri pembelajar. Prinsip motivasi intrinsik menyiratkan lebih dari sekadar beberapa kololari (akibat wajar) yang bisa bertindak sebagai "ujian" bagi potensi suatu teknik untuk menciptakan atau mempertahankan motivasi instrinsik. Cermati daftar berikut, setiap butir yang mewakili wajah prinsip motivasi intrinsik:

${ }^{5}$ Crookes dan Cahudron ${ }^{5}, 1991$, hal. 52-54 
1. apakah teknik tersebut menarik ketertarikan murni para siswa Anda? Apakah hal tersebut relevan dengan kehidupan mereka?

2. apakah tehnik disajikan dalam kondisi yang positif dan antusias?

3. apakah para siswa benar-benar sadar akan tujuan tehnik tesebut?

4. apakah siswa memiliki beberapa pilihan dalam: (a) memilih beberapa aspek tehnik tersebut? Dan/atau (b) menentukan bagaimana mereka memenuhi tujuan-tujuan teknik tersebut?

5. apakah teknik tersebut mendorong siswa untuk menemukan sendiri prinsip-prinsip atau aturan-aturan tertentu (dari Anda)?

6. apakah teknik tersebut mendorong siswa begitu rupa untuk mengembangkan atau menggunakan strategi efektif pembelajaran dan komunikasi?

7. apakah teknik tersebut mendukung - setidaknya untuk beberapa hal otonomi akhir dan ketidaktergantungan para siswa (dari Anda)?

8. apakah teknik tersebut mengejar negosiasi kooperatif dengan siswa lainnya di dalam kelas? Apakah ini merupakan teknik yang benar-benar interaktif?

9. apakah teknik tersebut menyajikan "tantangan yang masuk akal”?

10. apakah para siswa menerima umpan balik yang cukup atas kinerja mereka (dari sesama mereka atau dari anda)?

Dengan pengantaran teknik yang hati-hati yang menggabungkan sebagian besar kriteria tersebut, para guru bisa lebih terjamin dalam menawarkan perlakuan yang khusus dirancang untuk menyelesaikan tujuan yang mengejar motivasi intrinsik.Ini merupakan pilihan yang jauh lebih canggih dan efektif dalam mengambil suatu metode tertentu dan memprogramkannya ke dalam garis besar pokok pengajaran tanpa memandang diagnosa kebutuhan siswa.

Cara lain dalam memandang hubungan antara pendekatan dengan perlakuan digambarkan dalam daftar saran berikut ini untuk membangun rasa akan investasi strategis di dalam kelas. Setiap butir dari sepuluh pertimbangan adalah satu prinsip pembelajaran/pengajaran yang secara masuk akal diterima 
(lihat Brown 1994b, hal 189-215). Mereka adalah ciri-ciri “pembelajar bahasa yang baik" yang akan bijaksana bagi kita semua untuk dikejar untuk kepentingan siswa dalam kelas bahasa kedua. Setiap prinsip menyiratkan aktifitas-aktifitas tertentu yang mungkin layak.

\section{Kurangi Hambatan}

Bermain tebakan dan mengkomunikasikan permainan; lakukan bermain peran dan lelucon; nyanyikan lagu ; gunakan kelompok kerja; tertawa dengan siswa Anda; buat mereka berbagi ketakutan-ketakutan dalam kelompok-kelompok kecil.

\section{Mendorong Untuk Mengambil Resiko}

Pujilah siswa karena berusaha sungguh-sungguh mencoba bahasa (berbahasa); gunakan latihan kelancaran di mana kesalahan-keslahan tidak (perlu) dikoreksi disaat itu; beri tugas di luar kelas untuk berbicara atau menulis atau untuk mencoba berbahasa.

\section{Bangun Rasa Percaya Diri Siswa}

Beritahu para siswa secara terang-terangan (secara verbal atau non verbal) bahwa Anda benar-benar percaya mereka; suruh mereka membuat daftar kekuatan mereka, tentang apa yang mereka tahu atau apa yang mereka telah selesaikan, sejauh ini dalam pelajaran.

\section{Bantu Siswa Mengembangkan Motivasi Intrinsik}

Ingatkan siswa secara gamblang tentang penghargaan atas belajar bahasa Inggris; gambarkan (atau buatlah siswa untuk melihat) pekerjaan-pekerjaan yang membutuhkan bahasa Inggris; kecilkan arti ujian akhir untuk membantu para siswa melihat penghargaan bagi diri mereka sendiri di luar ujian akhir. 


\section{Tingkatkan Pembelajaran Kooperatif}

Arahkan siswa untuk berbagi pengetahuan mereka; kecilkan arti persaingan di antara siswa; buat kelas Anda berpikir sebagai sebuah tim; bentuklah sejumlah kelompok kerja kecil.

\section{Dorong Siswa Untuk Menggunakan Proses Otak Kanan}

Putar filem dan kaset di kelas; suruh siswa untuk membaca paragraf dengan cepat; lakukan latihan pembacaan sepintas lalu; lakukan "menulis" bebas secara cepat; lakukan latihan kelancaran berbicara di mana obyeknya adalah untuk membuat siswa berbicara (atau menilis) banyak tanpa dikoreksi.

\section{Tingkatkan Toleransi Terhadap Kerancuan}

Dorong siswa Anda untuk bertanya kepada anda, dan sesama siswa, ketika mereka tidak mengerti sesuatu; jagalah penjelasan teoritis tetap sederhana dan singkat; berhadapan dengan sedikit aturan di suatu waktu; kadang Anda bisa mengusahakan terjemahan ke bahasa ibu untuk menjelaskan kata atau makna.

\section{Bantu Siswa Menggunakan Intuisi Mereka}

Pujilah siswa karena tebakannya bagus; jangan selalu memberi penjelasan terhadap kesalahan - jadikan koreksi itu cukup saja: koreksi beberapa kesalahan yang terpilih, terutama kesalahan yang mengganggu pembelajaran.

\section{Jadikan Siswa Membuat Kesalahan Mereka Sebagai Sesuatu Yang Bekerja Untuk Mereka}

Rekam siswa yang berbicara dan suruh mereka mengenali kesalahan; biarkan para siswa menangkap dan mengkoreksi kesalahan sesama mereka; jangan selalu memberi mereka bentuk yang salah; dorong siswa untuk membuat 
daftar kesalahan-kesalahan mereka yang umum dan dorong mereka bekerja sendiri.

\section{Buatlah Siswa Menetapkan Tujuannya Sendiri}

Secara lugas dorong atau arahkan siswa untuk melihat di luar tujuan dalam kelas; buat mereka membuat daftar tentang apa yang akan mereka selesaikan sendiri di minggu tertentu; buat siswa membuat komitmen waktu tertentu di rumah untuk belajar bahasa; berikan pekerjaan dengan "penghargaan ekstra".

Di sini sekali lagi kita melihat contoh praktis cara suatu pendekatan yang dibuat menjadi prinsip terhadap pengajaran bahasa yang secara konsisten dan secara langsung mengarah ke tehnik-tehnik kelas praktis. Sepuluh maksim yang dibuat prinsip atau "aturan-aturan" untuk pembelajaran bahasa yang baik bisa memfokuskan guru pada kelas praktik suara.

\section{PENILAIAN}

Akhirnya, kematian metode-metode telah mendorong kita ke dalam domain pedagogi bahasa yang baru yang bernama pendekatan-pendekatan yang ditingkatkan dan teknik-teknik untuk menilai prestasi siswa dalam sasaran kurikulum. Metode lama tidak menawarkan apapun dalam cara teknik penilaian; pada hal terbaiknya metode lama mungkin menyiratkan proses berkelanjutan penilaian ketika metode tersebut dipraktikkan. Sekarang, bidang pengujian-bahasa telah menjamur menjadi bidang yang sangat maju dan canggih dengan beragam wajah.

Salah satu wajah ini adalah meningkatnya penekanan terhadap penilaian berjalan terhadap kinerja siswa ketika pelajaran mengalami kemajuan, atau yang secara umum disebut dengan evaluasi formatif. Dengan munculnya teknik untuk penilain berdasar-kinerja, perkembangan portofolio, inventaris produksi oral 
(berbicara), teknik kerja sama antarsiswa, dan rubrik pengujian otentik, kita secara cepat mengembangkan kapasitas untuk menyediakan program penilaian yang berjalan disepanjang garis besar pokok pengajaran siswa. Dengan proses formatif penilaian, para guru bisa membuat perubahan pedagogik di tengah-tengah pelajaran untuk secara lebih efektif mencapai tujuan-tujuan.

Gagasan bahwa evaluasi harus dibatasi menjadi penyajian akhir, akhirdari-pelajaran atau akhir-unit dari tes menjadi lenyap. Namun, penting untuk dicatat bahwa evaluasi sumatif juga merupakan komponen penting dari program bahasa. Perbedaan antara filsafat ujian sumatif yang sekarang ada dengan perkiraan yang ada di belakang metode-metode - bahwa "satu ukuran bisa untuk semua" - bisa dilihat dalam serangkaian deretan penilain yang luas yang mencakup ketrampilan pemahaman maupun produksi (berbahasa atau berbicara/menulis), serangkaian tugas-tugas penilaian, tes-tes individual (termasuk tes melalui komputer), dan meningkatnya perhatian terhadap sifat-sifat komunikatif tes.

\section{Kesimpulan}

"Metode-metode" sebagaimana yang kita pahami secara historis dalam pemahaman profesi, bukanlah persoalan yang relevan dalam proses diagnosa, perlakuan, dan penilaian para pembelajar bahasa asing. Kita telah melewati masa kegelapan pengajaran bahasa ketika paket ramuan ajaib berisi beberapa pilihan. Meskipun jejak-jejak ramuan yang bersifat prinsipil dari metode lama masih efektif menemukan jalannya ke dalam pilihan-pilihan pedagogik kita untuk perlakuan, profesi kita telah muncul ke era pemahaman sejumlah besar tujuan dan konteks pengajaran bahasa, dan bahkan sejumlah besar kebutuhan siswa, gaya belajar, dan sifat-sifat yang berpengaruh. Ketika para guru dan penatar guru mengembangkan dan melaksanakan teknik-teknik dalam kelas, mereka bisa mengambil manfaat dengan mendasarkan apapun yang mereka lakukan dalam 
prinsip-prinsip yang mapan atas pembelajaran dan pengajaran bahasa. Dengan melakukan hal tersebut, mereka tidak akan terlalu melaksanakan metode yang sudah ditetapkan sebelumnya - dan yang mungkin tidak efektif - dan secara langsung lebih tanggap terhadap tujuan dan sasaran para siswanya. 


\section{DAFTAR BACAAN}

Abdul Wahab Rosyidi dan Mamlu'atul Ni'mah, Memahami Konsep Dasar Pembelajaran Bahasa Arab, UIN Maliki Press, tahun 2012.

Bailey, Onwuegbuzie dan Daley (2000), Correlatesof anxiety of trees stage of the foreign language learning process, Journal of language ang sosiol psychology.

Basil Hatim and Jeremy Munday, Translation An Advan Resource Book, Routledge Taylor ang Francis Group, London And NewYork. 2004

Conny Semiawan, Belajar dan Pembelajaran Dalam Taraf Usia Dini Jakarta:Prihallindo, 2002.

Dedy Sugono (ed), Kamus Besar Bahasa Indonesia, Jakarta: Pusat Bahasa, Depdiknas, 2008.

Diah, Muhammad. Analisis Kesalahan (Bahan Kuliah), Palembang. Program Pascasarjana Universitas Sriwijaya: tt.

Dougas Brown, Principles Of langaunge Learning and Teaching, San Fransisco State University, Fourth Edition.

Emzir, Metodologi Penelitian Kualitatif: Analisis Data, Rajawali Press, Jakarta; 2011.

Fuad Abdul Hamied, Proses Belajar Mengajar Bahasa. Jakarta: Depdikbud, 1989.

Gadner, Robert, \& Maclyntyre, Peter D, 1991, An Instruentel Motivation In Language Study: Who Say it isn't effective? Studies In Languange Second Languange Acquisition, 13: 57-72

Gadner, Robert, \& Maclyntyre, Peter D, 1993, A Student's contributions to Second Languange Learning, Part II: Affective variables, Languange Teaching 26: 1-11.

Gadner, Robert, \& Maclyntyre, Peter D, 1992, Integrative Motivation, Induced anxiety, and languane learning in a controlled environment. Studied in Second Languange Acquisition. 14: 197-214.

Greerberg, Joseph. H (Ed), 1963, Universals Of language, Cambridge, M.I.T Press.

Greerberg, Joseph. H, 1966, Langaunge Universals, The Hague: Mouton Pubhlisher.

Gregersen (2003), Te err in human; A reminded to teacher oflanguage anxious student Annal. 
Ganschow et al., 1994; Sparks \& Ganschow, 1995, 1993a, 1993b, 1991, Differences in language performance among high, average and low anxious college foregn language leaners, Modern language journal, $788,41-45$

Horwitz, It ain't over, 2000: On foreign language anxiety, first language deficits and the confounding variable, Modern language journal, 21: 112-126

Kridalaksana, Kamus Linguistik. Jakarta: Erlangga, 1984.

,Struktur, Kategori dan Fungsi Dalam Teori Sintaksis ,Jakarta, Universitas Katholik Indonesia, 2002.

Lado, R, Linguistics Across Culture: Applied Linguistics for Language Teacher. An Arbor: University ofMichigan Press, 1968.

Nana Sudjana, Penilaian Hasil Proses Belajar Mengajar, Bandung: Remaja Rosdakarya. 2005.

Radliyah Zainudin, dkk.,Metodologi dan Strategi Alternatif Pembelajaran Bahasa Arab, Yogyakarta: Pustaka Rihlah Group, 2005.

Tarigan, Henry Guntur dan Djago Tarigan. Pengajaran Analisis Kesalahan Berbahasa, Angkasa Bandung: 1990 